원 저

\title{
The Response of Antimycobacterial Antibody to Therapy; A Longitudinal Study of Antibody Titers in Pulmonary Tuberculosis
}

\author{
Y.S. Shim, M.D., M.J. Cho, M.D*., C.Y. Cha, M.D.* \\ K.Y. Kim, M.D. and Y.C. Han, M.D. \\ Department of Medicine, Microbiology* and Tuberculosis Research Institute \\ College of Medicine, Seoul National University
}

=국문초록 $=$

결핵치료에 따른 항결핵균항체 역가의 종적변화에 관한 연구

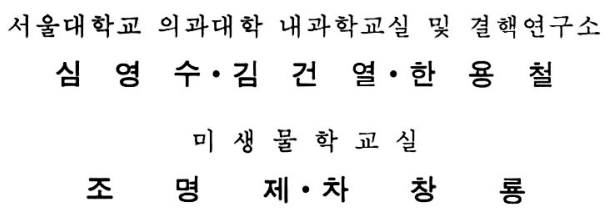

\begin{abstract}
결핵 치료에 따른 항결핵균항체의 변화를 관찰하기 위하여 활동성 페결핵 환자를 대상으로 효소 결합면역분석법을 이용해서 항결핵균항체의 역가를 측정하였다.

중증폐결핵 환자군에서는 치료 초기에는 항결핵균항체가 증가하였으나 치료중에 감소하는 추세를 보였다. 그러나 경증 및 중등증 환자에서는 치료에 따른 유의한 변화가 관찰되지 않았다.

경증 및 중등증 환자군과 중증 환자군 사이의 항결핵균항체 반응의 차이는 두 군간의 면역 반응 이 다르기 때문이라고 추론된다.

이상의 결과로 항결핵균항체를 연속적으로 측정하는 것이 결핵환자의 추구 검사에 도움이 될 것 으로 사료된다.
\end{abstract}

\section{INTRODUCTION}

Tuberculosis still continues to be a loathsome disease and is a significant public health problem in Korea.

Rapid diagnosis of active tuberculosis and accurate assessment of treatment response are essential for the management and control of tuberculosis.

The paper was presented at the 26 th IUAT world conference

본 연구는 1986 년도 서울대학교병 원 임상연구비 보조로 이 루어진 것임.
The accurate assessment of response to therapy in long standing tuberculosis is a formidable obstacle to be solved.

Until now, the response has been assessed by bacteriological examination and clinical assessment").

Clinical assessment is notorious for its inaccuracy. Sputum smear is positive in $60 \%$ of patients at most and also is not a definite method.

The definitive means of establishing the diagnosis of tuberculosis is culture of the organism. In addition to expense, the major problem with currently available culture techniques is that it requires 6 to 8 
weeks to get positive culture and/or indentification of species.

Alternative methods for the rapid diagnosis of tuberculosis are obviously needed.

The development of sensitive immunological method and preparation of refined antigen give a hope that immunologic test could be a useful tool for the diagnosis and control of tuberculosis.

Several studies on immunological monitoring of treatment response, were published with conflicting result ${ }^{2 \sim 5)}$.

To examine these differences, we studied the change of antimycobacterial antibody response in fresh active tuberculosis patients during therapy with enzyme-linked immunosorbent assay using sonicate mycobacterial cell extract as antigen.

\section{Material and Method}

\section{Material}

The study was conducted in 2 stages. Among the patients who visited Seoul National University Hospital from Jan. 1984 to Mar. 1986, newly diagnosed active patients with favorable treatment response to the standard regimen were included in this study (Table 1). In stage 1, total of 103 patients was randomly selected and divided into three groups; 47 were minimal active tuberculosis, 35 were moderately and 21 were far advanced tuberculosis according to the 1969 National Tuberculosis and Respiratory Disease Association criteria. From these patients, serum samples were collected ramdomly during and after treatment. In stage2, serial samples were collected from 14 minimal, 11 moderately advanced and 6 far advanced patients.

The serum was seperated from clotted blood promptly after collection and stored at $-20^{\circ} \mathrm{C}$ until used to analyse.

\section{Antigen Preparation}

The antigen was prepared as previously described $^{6,7)}$. In brief, mycobacterium tuberculosis strain H37Rv was cultured in Sauton's synthetic media for 3 4 weeks and the bacilli were killed with phenol. They were sonicated for 13 minutes using ultrasonicator.

The sonicate was centrifuged at $10,000 \mathrm{rpm}$ for 20 minutes and the supernatant was named as TE antigen.

\section{ELISA Method}

ELISA test was performed as previously described $^{6.7}$. In brief, the TE antigen was diluted with carbonated buffer solution to the concentration of $10 \mu \mathrm{g} / \mathrm{ml}$ and $100 \mu \mathrm{l}$ of diluent was pipetted into each well of polystyrene 96-well EIA plate for antigen fixation.

After blocking with bovine serum albumin, $100 \mu$ 1 of patients serum of 1 in 400 dilution was added.

After reaction, $100 \mu \mathrm{l}$ of peroxidase conjugated antihuman IgG diluted 1 in 500 was added. Substrate solution containing orthophthalene diamine was used and the absorbance was read at $492 \mathrm{~nm}$ with multiscanner.

\section{RESULT}

\section{Result of Stage 1}

Fig. 1 showes the result of random samples from the initiation of therapy to 1 year of follow up.

The initial values were 0.3581 for minimal group,

Table 1. Characteristics of Patients

\begin{tabular}{lcc}
\hline \hline & Stage 1 & Stage 2 \\
\hline Extent & & \\
Minimal & 47 & 14 \\
Moderately advanced & 35 & 11 \\
Far advanced & 21 & 6 \\
Sex & & \\
Male & 55 & 20 \\
Female & 48 & 11 \\
\hline Total & 103 & 31 \\
\hline
\end{tabular}




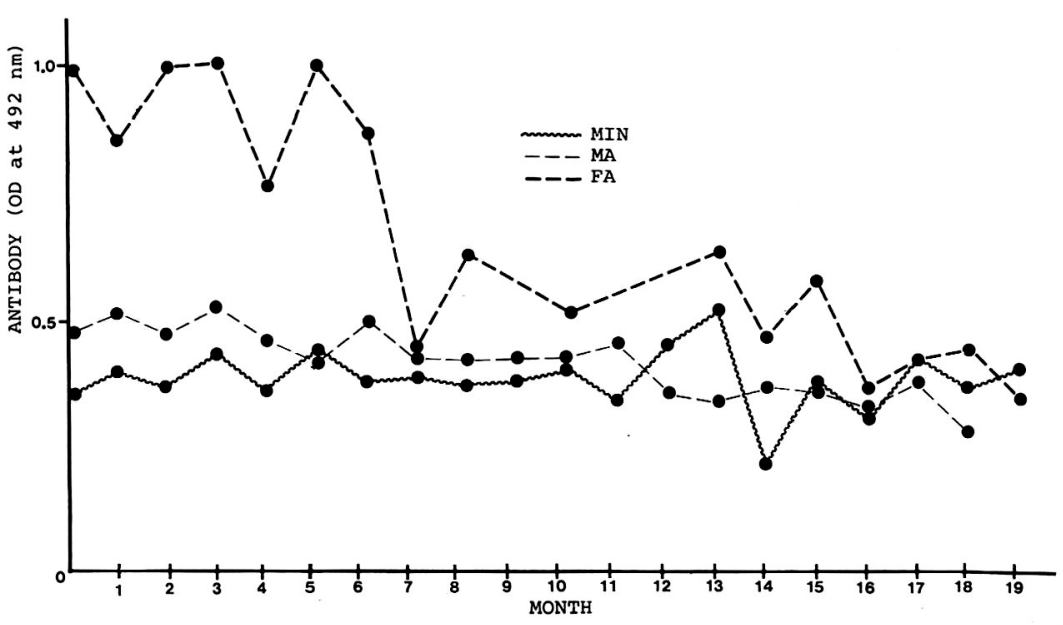

Fig. 1. Mean ELISA titers following the initiation of treatment of tuberculosis.

MIN : Minimal tuberculosis. MA : Moderately advanced tuberculosis, FA : Far advanced tuberculosis

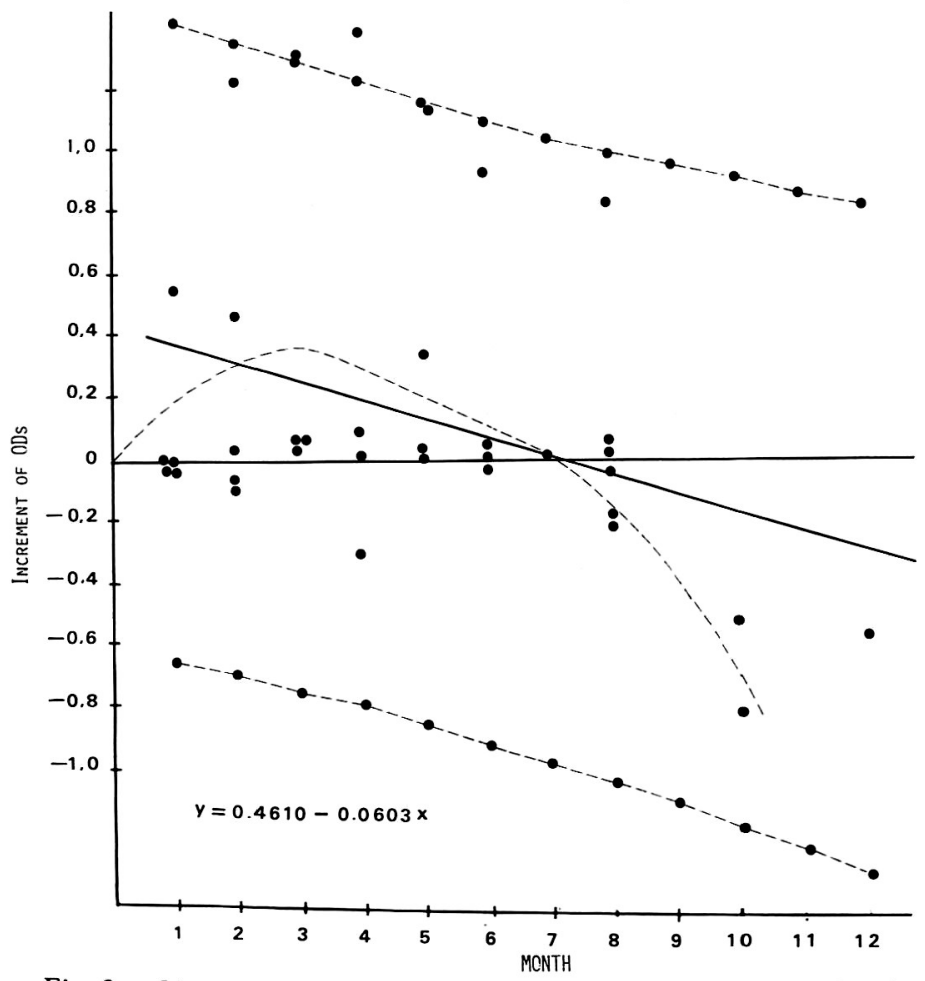

Fig. 2. Linear regression analysis of difference in optical density following the initiation of treatment of far advanced tuberculosis.

0.4815 for moderately advanced and 0.9837 for far advanced group.

With treatment, the absorbance of minimal and moderately advanced group did not change significanly during treatment follow-up.

In far advanced group, the absorbance increased 
initially up to 1.1597 , but started decreasing from 6 th month and reached the other group's value by the one and one half year follow up.

\section{Results of Stage 2}

In stage 2 study, the difference between the

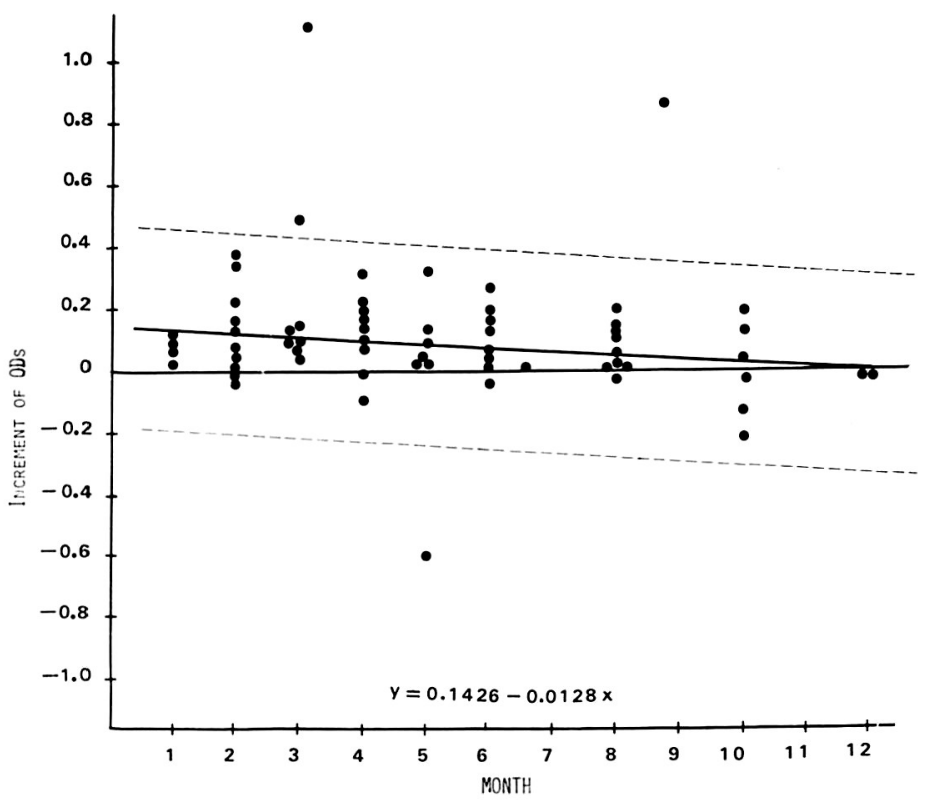

Fig. 3. Linear regression analysis of difference in optical density following the initiation of treatment of minimal tuberculosis.

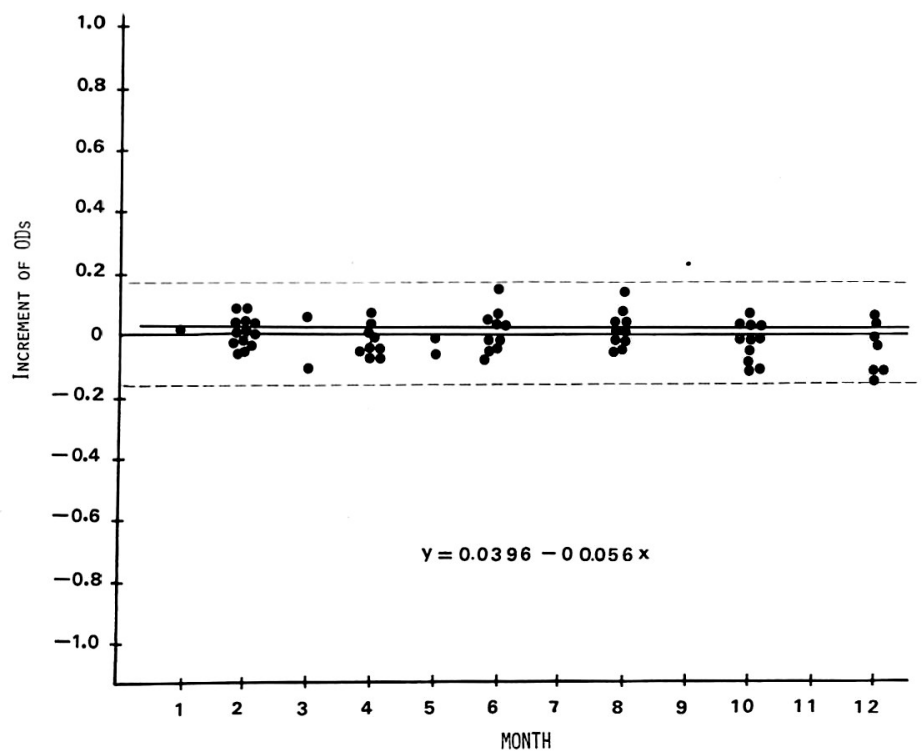

Fig. 4. Linear regression analysis of difference in optical density following the initiation of treatment of moderately advanced tuberculosis. 
measured value and pretreatment value were examined.

Fig. 2 showes the change of absorbance during treatment in 6 patients with far advanced tuberculosis.

The regression equation was $Y=0.4610-0.0603 \mathrm{X}$ with $r$ value of 0.34 and $p$ value was $<0.05$ which was statistically significant.

By plotting the mean values of antibody change, we could draw a imaginary line. This result showed that the antibody level was decreasing with treatment after initial elevation. This result is fairly well coincident with stage 1 result. The point of return to initial value would be around $6 \sim 7$ months, but the exact point could not be confirmed because of small sample size.

In moderately advanced group, the regression equation was $\mathrm{Y}=0.1426-0.012 \mathrm{X}$ and no statistical significance was found (Fig. 3).

In minimal group, the regression equation was $\mathrm{Y}=0.0396-0.0056 \mathrm{X}$, but the slope did not have any statistical significance (Fig. 4).

These data were also coincident with stage 1 result.

\section{DISCUSSION}

With the advance of immunology, numerous attempts have been made toward the development of a serodiagnostic test for tuberculosis ${ }^{8}$.

Diena summarized the requirements for the ideal serological test for tuberculosis as follows'):

1) It must differentiate between antibody responses due to natural infection and to Bacille CalmetteGuerin (BCG) vaccination. 2) It should be a diagnostic aid in case-finding surveys. 3) It should be of use in the monitoring of chemotherapy. 4) It should assist in the diagnosis of other mycobacterial infections. 5) It should be of value in the diagnosis of extrapulmonary tuberculosis in which radiological studies are unhelpful and specimens are not easily obtained.

The search for a serologic test for early diagnosis of infection and detection of recurrence has been continued since the report of Widal and Le Sourd in $1901^{8)}$.

Viljanen.et.al reported that the antibody titer in far advanced patients was higher than minimal active patients ${ }^{10)}$. Similar results was reported by $u^{6,7)}$.

Even though the mean antibody activity of patients with active disease was significantly different from normal control, the range of antibody activity of the active patients and normal control overlapped significantly, thereby diminishing the potential usefulness of serologic test as a diagnostic tool ${ }^{6,7)}$.

Winters et al also found no significant difference between patients with active disease and those in clinical remission and expressed doubt about the possibility of diagnostic usefulness ${ }^{11}$. Zeiss et al recommended to combine the serologic data with sputum smear result to increase the specificity and sensitivity of serologic test ${ }^{12}$.

After reviewing all these results, Grange concluded that no satisfactory technique has been developed yet for the early diagnosis of tuberculosis ${ }^{8}$.

Serologic test was also applied for the monitoring of chemotherapy and conflicting results had been reported.

In 1967, Favez reported that the antibody titers showed a consistant drop in $74 \%$ of cases in 2 months, and in $88 \%$ of the cases in three months ${ }^{2}$.

Khomenko, et al. reported that antibody titer was decreasing from 6 th months and concurred with the report of Favez. ${ }^{13)}$

Kaplan \& Chase reported that antibiotics treat. ment increased the percentage of responders from $46 \%$ to $60 \%$ in new cases and from $66 \%$ to $75 \%$ in relapse cases and increased the concentration of antibodies $^{3)}$.

Also, Daniel et al. observed the ELISA titers 
remained essentially stable during the 16 months follow up after the initiation of therapy ${ }^{4}$.

From our institution, Yoon et al. reported that antibody titer started to decreasing from the 3-4 months after treatment and concurred with Favez and Khomenko's report ${ }^{5)}$.

But, Yoon's report had following problems.

1) The study group between early and late phase of treatment was not identical. 2) As the antibody titer during treatment would be influenced by the pretreatment value, the interpersonal comparison with measured value would produce biased result.

To overcome these problems, present study was conducted with serial sample and the difference between measured value and pretreatment value were examined.

In the previous reports, the change of antimycobacterial antibody level had no relation with the severity. Contrary to the previous reports, our result suggested that the change of antibody level was related with the disease severity. In far advanced group, initial antibody level was high and increased during the early phase of treatment, which was similar to the Kaplan \& Chase's result. The level started decreasing from 6 th month of treatment and this was in accord with Khomenko's report. In moderately advanced and minimal active patients, as Daniel,et al. reported, there was no significant difference of antibody level during and after treatment. These result suggested that the response of antibody was complex.

The difference of antibody response could be explained by the humoral immunity of tuberculosis infection. In 1977, Bhatnagar, et al. studied the im. munologic status and compared with their clinical patterns to explain the reasons for the development of different clinical forms of tuberculosis in different persons ${ }^{14)}$. He reported that there was an inverse relationship between cell mediated and humoral immune response and the spectrum of immunologic abnormalities correlated with the clinical forms and nutritional status. Lenzini,et al., in 1977, classified the spectrum of human tuberculosis into 4 different groups, i.e. reactive (RR), reactive intermediate (RI), unreactive intermediate (UI) and unreactive (UU) and found relation with the extent of disease ${ }^{15}$. Both report suggested that, in extensive disease. cellular immunity was depressed and exuberant antibody production was found. Also, the immune spectrum could be changed by chemotherapy from unreactive to reactive group. Daniel et al reported that the-immune response was related with radiographical acuteness rather than to the state of nutrition or extent of disease ${ }^{16}$.

To explain these immunological spectrum, the cellular response was studied. Schmitt et al found that marked increase in proliferative activity of monocytopoiesis and premature monocyte release from marrow in active tuberculosis ${ }^{17}$. Ellner reported that the monocyte acted as suppressor adherent cells and depressed the immune response ${ }^{18)}$. Ket $z$ et al studied the qualitative and quantitative alterations in the mononuclear cells of patients with active tuberculosis ${ }^{19}$. They found that, in the presence of adherent cells, there was a consistent reduction in the absolute number of circulating T cells. In addition, untreated patients has a relative increase in the percentage of $T_{G}$ cells and a concomitant decrease in $T_{M}$ cells. These alterations in the subsets of $T$ cells were reversed after four to six weeks of therapy. In further study of monocyte, Tweardy, et al. reported that surface expression of DR antigen of monocyte had relation with immune response ${ }^{20)}$.

These reports could explain the existence and changing patterns of immune spectrum of tuberculosis, and also the result of present study. The difference of antibody response between minimal active and moderately advanced group versus far advanced group could be explained by the difference of immune response. The minimal active and moderately advanced tuberculosis could be classified as Lenzini's RR or RI group, in which no signifi- 
cant change of humoral immunity was found. The far advanced group could be classified as UI or UU group. In this group, cellular immunity was depressed and humoral immunity was increased with exuberant antibody production. With chemotherapy, the cellular immunity recovered and the antibody response would decrease and reached the level of minimal active and moderately advanced group.

The individual variation of antibody response in a same group could be explained by genetical segregation proposed by Lagrange et $\mathrm{al}^{21)}$. Further study of humoral immunity should be extended to include the cell-mediated immune response for clearer understanding of tuberculosis. Also, the detection of circulating immune complex, detecting antigen instead of antibody, should be combined with the change of antibody concentration for early detection of active disease and to explain the variation of antibody response $\mathrm{e}^{22 \sim 25)}$.

\section{SUMMAY}

The antibody response of antimycobacterial antibody during and after chemotherapy was studied with ELISA in fresh active tuberculosis patients.

In far advanced tuberculosis, the antimycobacterial antibody level was increased initially with treatment, but, was decreased during the later phase of treatment. In minimal active and moderately advanced group, no significant change of antibody level was detected. The pattern of antimycobacterial antibody response was different between minimal and moderately advanced group versus far advanced group.

The difference of immune response could be important factor for this difference.

Serial examination of antimycobacterial antibody titer would be helpful for the follow up of tuberculosis patient.

\section{Acknowledgement}

The TE antigen was kindly supplied by Dr. S.J. Kim of Korean Tuberculosis Institute, Seoul, Korea

\section{REFERENCES}

1) Glassroth JG, Rodins AG, Sniders DE: Tuberculosis in the 1980s New Engl J Med 302:1451, 1980

2) Favez GS: Distinct circulating antibodies demonstrated in tuberculosis patients; correlation between changes in antibody content of serum and clinical evolution. Ann NY Aca Sci 154:128, 1968

3) Kaplan MH, Chase MW: Antibodies to mycobacteria in human tuberculosis I. Development of antibodies before and after antimicrobial therapy. J Inf Dis 142:852, 1980

4) Daniel TM, Debanne SM, van der Kuyp F: Enzymelinked immunosorbent assay using mycobacterium tuberculosis antigen 5 and PPD for the serodiagnosis of tuberculosis. Chest 88:388, 1985

5) Yoon KS, Lee CT, Shim Y, Han YC, Cho MJ, Cha $\mathrm{CY}$, Chang WH: Antimycobacterial antibody response in patients with pulmonary tuberculosis during chemotherapy. Tuber Respir Dis 33:79, 1986

6) Cha CY, Kim SJ: Antibodies against mycobacterium tuberculosis in the immunoglobulin classes in the sera from the patients with pulmonary tuberculosis. Tuber Respir Dis 30:105, 1983

7) Shim Y, Kim CS: Diagnostic significance of enzyme-linked immunosorbent assay in tuberculosis. Chung-Ang J Med 9:187, 1984

8) Grange JM: The humoral immune response in tuberculosis: Its nature, biological role and diagnostic usefulness. Adv Tuberc Res 21:1, 1984

9) Diena BB: Serology in tuberculosis and the bentonite flocculation test. Can Med Ass J 99:763, 1968

10) Viljanen MK, Eskola J, Tala E: Enzyme-immunosorbent assay for antibodies to purified protein derivative of tuberculin (PPD). Eur J Respir Dis 63: 257, 1982

11) Winters WD, Cox RA: Serodiagnosis of tuberculosis by radioimmunoassay. Am Rev Respir Dis 124:582, 1981

12) Zeiss $C R$, Kalish SB, Erlich KS, Levitz D, Metzger E, Radin R, Phair JP: IgG antibody to purified 
protein derivative by enzyme-linked immunosorbent assay in the diagnosis of pulmonary tuberculosis. Am Rev Respir Dis 130:845, 1984

13) Khomenko AG, Averbach MM, Litvinov VI, Gergert VJ: Effects of chemotherapy on the immunological characteristic of patients with primary desturctive pulmonary tuberculosis. Bull WHO 62:763, 1984

14) Bhatnagar R, Malaviya AN, Narayanan S, Rajgopalan P, Kumar R, Bharadwaj OP: Spectrum of immune response abnormalities in different clinical forms of tuberculosis. Am Rev Respir Dis 115:207, 1977

15) Lenzini L, Rottoli P, Rottoli L: The spectrum of human tuberculosis. Clin Exp Immunol 27:230, 1977

16) Daniel TM, Oxtoby MJ, Pinto E, Moreno E: The immune spectrum in patients with pulmonary tuberculosis 123:556, 1981

17) Schmitt E, Meuret G, Stix L: Monocyte recruitment in tuberculosis and sarcoidosis. Brit J Hemat 35:11, 1977

18) Ellner JJ: Suppressor adherent cells in human tuberculosis. J Immunol 121:2573, 1978

19) Katz P, Goldstein RA, Fauci AS: Immunoregulation in infection caused by mycobacterium tuberculosis: The presence of suppressor monocytes and the alteration of subpopulations of T lymphocytes. J Inf
Dis 140:12, 1979

20) Tweardy DJ, Schacter BZ, Ellner JJ: Association of altered dynamics of monocyte surface expression of human leukocyte antigen DR with immunosuppression in tuberculosis. J Inf Dis 149:31, 1984

21) Lagrange $P H$, Hurtrel B, Thickstun PM; Immunological behavior after mycobacterial infection in selected lines of mice with high or low antibody responses. Infect Immun 25:39, 1979

22) Carr RI, Chakraborty AK, Brunda MJ, Davidson PT, Damle PB, Hardtke MA, Gilbride KJ, Minden $P$ : Immune complexes and antibodies to BCG in sera from patients with mycobacterial infections. Clin Exp Immunol 39:562, 1980

23) May JJ, Katilus J, Henson M, Dreisin R: The purification and identification of circulating immune complexes in tuberculosis. Am Rev Respir Dis 128: 920, 1983

24) Samuel AM, Ashtekar MD, ganatra RD: Significance of circulating immune complexes in pulmonary tuberculosis. Clin Exp Immunol 58:317, 1984

25) Bhattacharya A, Ranadive SN, Kale M, Bhattacharya S: Antibody-based enzyme-linked immunosorbent assay for determination of immune complexes in clinical tuberculosis. Am Rev Respir Dis 134:205, 1986 